\title{
Kajian Karakteristik Arsitektur Omah Sengen Etnis Jawe Di Banten Lor
}

Muhammar Khamdevi

e-mail:m.khamdevi@gmail.com

Program Studi Arsitektur Universitas Matana

\section{Abstrak}

Berbeda dengan wilayah Banten Kidul (Banten Selatan) yang didiami oleh etnis Sunda Banten, wilayah Banten Lor (Banten Utara) justru didiami oleh suku Jawe (Jawa) yang ada sejak jaman Kesultanan Banten. Kesultanan ini merupakan wilayah bawahan dari Kesultanan Cirebon dan selain itu juga memiliki kedekatan hubungan politik dengan Kesultanan Palembang. Di wilayah ini terdapat beberapa rumah tradisional yang bernama Omah Sengen (Rumah Dulu) atau Omah Panggang Pe, terutama di Cilegon dan di Serang. Sayangnya rumah tradisional ini tidak begitu mendapat perhatian lebih dari kajian arsitektur dan sebentar lagi jumlahnya akan semakin menyusut bahkan lenyap. Maka penelitian ini menjadi penting untuk mencoba meneliti dan mendokumentasikan karakter arsitekturnya. Penelitian ini menggunakan metode penelitian kualitatif dengan pendekatan studi kasus, dengan cara menganalisis karakteristik bangunannya secara arsitektural; spasial, fisik dan figural, dan stilistik. Bagaimanakah karakteristik rumah tradisional di Banten Lor? Penelitian ini diharapkan dapat menambah dan melengkapi referensi-referensi keilmuan, terutama mengenai rumah tradisional di wilayah Banten.

Kata kunci: rumah tradisional, omah sengen, panggang pe, karakteristik arsitektur, pusaka arsitektur

\section{Abstract}

In contrast to the Banten Kidul (South Banten) area which was inhabited by SundaBantenese ethnic group, the Banten Lor (North Banten) area was actually inhabited by the Jawe (Javanese) ethnic group which had existed since the days of the Banten Sultanate. This sultanate is a subordinate area of the Cirebon Sultanate and besides that it also has close political relations with the Palembang Sultanate. In this area there are several traditional houses called Omah Sengen (Old House) or Omah Panggang Pe, especially in Cilegon and in Serang. Unfortunately, this traditional house does not get much attention from architectural studies and soon the number will be shrinking and even disappearing. So this research becomes important to try to research and document its architectural character. This study uses a qualitative 
research method with a case study approach, by analyzing the architectural characteristics of the building; spatial, physical and figural, and stylistic. What are the characteristics of traditional houses in Banten Lor? This research is expected to add and complete scientific references, especially regarding traditional houses in the Banten region.

Keywords: traditional house, omah sengen, panggang pe, architectural characteristic, architectural heritage

\section{Pendahuluan}

Suku Jawe banyak bermukim di wilayah Banten Lor, seperti di wilayah Serang, Cilegon, hingga Cikande. Keberadaan mereka diperkirakan muncul pada masa Kesultanan Banten. Pada abad ke-16, Kesultanan Cirebon dan Kesultanan Demak melakukan ekspansi ke kawasan pesisir barat Pulau Jawa, terutama Kerajaan Hindu Pajajaran yang diduga akan melakukan perjanjian dengan Portugis. Dipimpin oleh Maulana Hasanuddin, putra Sunan Gunung Jati (Syarif Hidayatullah), penaklukkan tersebut berhasil dari Banten Pesisir hingga ke Banten Girang. Lalu akhirnya Kesultanan Banten dibentuk dengan ibukota Surosowan di wilayah pesisir yang sekarang lebih dikenal dengan Banten Lama. Walau sebenarnya kesultanan ini masih di bawah pengaruh Kesultanan Demak dan Kesultanan Cirebon, Kesultanan Banten ini menguasai sebagian besar Jawa Barat dan Selatan Sumatera (Tjandrasasmita, 2009).

Namun ada dugaan pula bahwa etnis Jawe ini sudah ada sejak jaman mundurnya Kedatuan Sriwijaya dan kemunculan Kerajaan Palembang dan Jambi di Sumatera, di mana mereka bermigrasi dari Kerajaan Mataram Kuno ke wilayah Banten Girang. Namu hal ini belum diperkuat dengan bukti-bukti ilmiah.

Tabel 1. Angka Dalam Bahasa Jawe Dengan Bahasa Lainnya

\begin{tabular}{|c|c|c|c|c|c|c|c|c|}
\hline Indonesia & Jawe & $\begin{array}{c}\text { Jawe } \\
\text { Bebasan }\end{array}$ & $\begin{array}{c}\text { Cirebona } \\
\text { Bagongan }\end{array}$ & $\begin{array}{l}\text { Cirebon } \\
\text { Bebasan }\end{array}$ & $\begin{array}{c}\text { Jawa } \\
\text { Ngoko }\end{array}$ & $\begin{array}{c}\text { Jawa } \\
\text { Kromo }\end{array}$ & $\begin{array}{c}\text { Palembang } \\
\text { Bebaso }\end{array}$ & $\begin{array}{c}\text { Palembang } \\
\text { Sari-sari }\end{array}$ \\
\hline Satu & Siji & Sios & Siji & Setunggal & Siji & Setunggal & Sios & Sikok, Eso \\
\hline Dua & Roro & Kale & Ro & Kalih & Loro & Kalih & Kale & Duo \\
\hline Tiga & Telu & Tige & Telu & Tiga & Telu & Tigo & Telu & Tigo \\
\hline Empat & Papat & Sekawan & Papat & Sekawan & Papat & Sekawan & Sekawan & Empat \\
\hline Lima & Lime & Gangsal & Lima & Gangsal & Limo & Gangsal & Gangsal & Limo \\
\hline Enam & Enem & Enem & Enom & Enem & Enem & Enem & Genep & Enam \\
\hline Tujuh & Pitu & Pitu & Pitu & Pitu & Pitu & Pitu & Pitu & Tuju \\
\hline Delapan & Wolu & Wolu & Wolu & Wolu & Wolu & Wolu & Wolu & Lapan \\
\hline Sembilan & Sange & Sange & Sanga & Sanga & Songo & Songo & Songo & Sembilan \\
\hline Sepuluh & Sepoloh & Sedase & Sepuluh & Sedasa & Sepuluh & Sedoso & Sedoso & Sepoloh \\
\hline
\end{tabular}

Dari diskusi dengan para ahli linguistik melalui FGD (Forum Group Discussion), bahasa Jawe lebih dekat dengan bahasa dan logat Jawa di Cirebon dan wilayah pesisir utara Jawa Tengah (Brebes dan Tegal), namun dengan beberapa pembendaharaan kata Bahasa Sunda dan dengan perbedaan akhiran “ $\partial$ ” (e schwa) yang mirip dengan Bahasa Melayu pesisir dan laut, serta 
semenanjung Malaysia (Johor - Riau). Yang unik lagi, angka "satu" disebut "sios" yang tidak umum di wilayah Jawa lainnya, yang hal ini mengingatkan juga pada bahasa Palembang "Bebaso" (halus) . Kata "sios" ini mungkin bentuk krama dari "siji" selain "setunggal".

Diketahui bahwa sempat ada hubungan politik hingga konflik antara Kesultanan Palembang dengan Kesultanan Banten. Selain itu, Kesultanan Palembang juga muncul ketika Kerajaan Palembang berubah menjadi kerajaan Islam karena pengaruh Kesultanan Demak. Pada abad ke17, Kesultanan Banten melemah ketika menghadapi konflik dengan Kesultanan Mataram Islam yang dibantu Kesultanan Palembang (Ooi, 2004).

Rumah tradisonal di Cilegon dan di Serang biasa disebut "Omah Panggang Pe" atau "Omah Sengen" (Rumah Dulu). Kata "Sengen" dalam bahasa Cirebon adalah "Bengen" yang artinya dulu. Panggang Pe merupakan tipe jenis rumahnya, yang merupakan jenis rumah yang paling dasar dan sederhana selain tipe-tipe Rumah Jawa seperti Omah Kampung, Omah Limasan maupun Omah Joglo (Prijotomo, 1995).

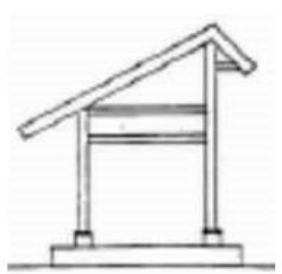

Panggang Pe

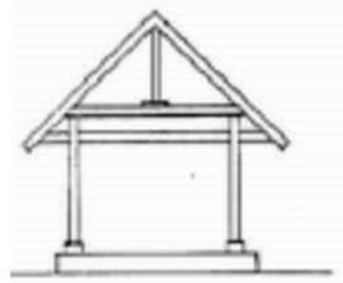

Kampung

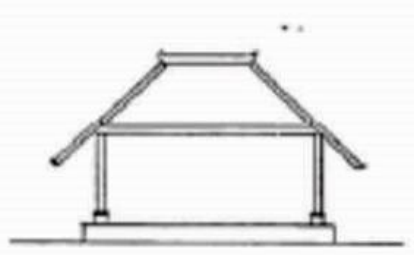

Limasan

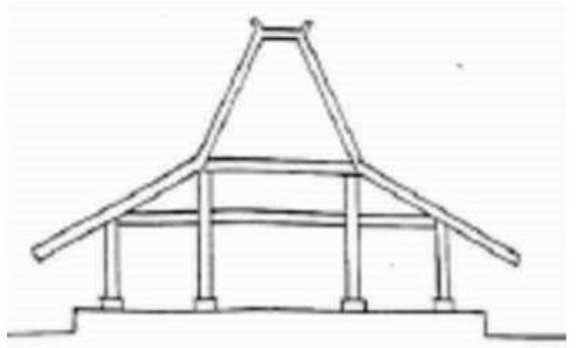

Joglo

Gambar 1. Jenis-jenis Omah Jawa Pokok

Menurut Dakung (1982), rumah Panggang Pe adalah bangunan yang diadopsi dari bangunan untuk menjemur hasil pertanian dan perikanan. Rumah ini juga disebut Cakrik dan memiliki beberapa jenis, seperti:

1. Panggang Pe Pokok, ia memiliki empat atau enam tiang atau saka. Setengah tiang lebih rendah dari tiang yang lain. Biasanya digunakan untuk rumah rakyat biasa, warung, dan pos ronda.

2. Gedhang Salirang, ia merupakan gabungan dari dua panggang pe, di mana salah satunya lebih tinggi.

3. Empyak Satangkep, ia merupakan gabungan dari dua panggang pe, di mana keduanya sama tinggi.

4. Gedhang Satangkep, ia merupakan gabungan dari dua panggang pe Gedhang Salirang bagian depannya, di mana keduanya sama tinggi.

5. Cere Gancet, ia merupakan gabungan dari dua panggang pe Gedhang Salirang bagian Belakangnya, di mana keduanya sama tinggi.

6. Trajumas, ia lebih panjang dari Panggang Pe Pokok, memakai tiga pengeret dan enam dengan dua buah bidang atap. 
7. Barengan, ia merupakan gabungan dari beberapa Panggang Pe Pokok yang berderet yang saling membelakangi satu sama lain.
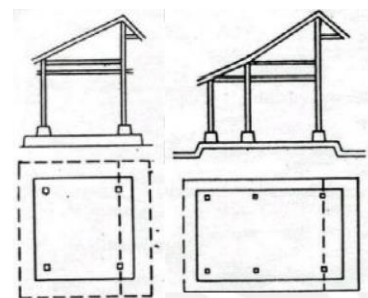
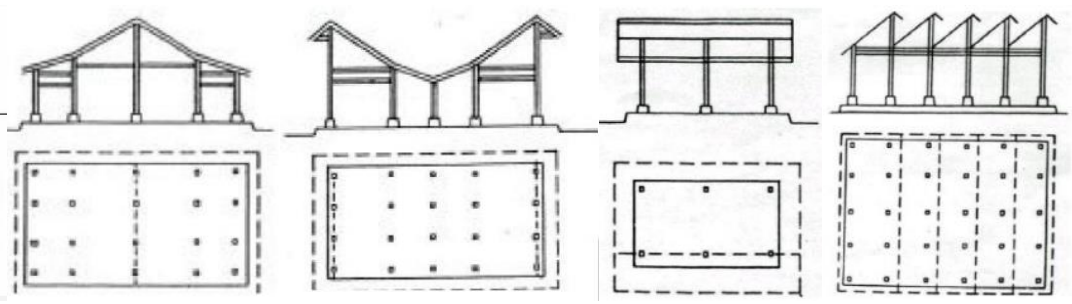

Gambar 2. Jenis-jenis Rumah Panggang Pe (dari kanan ke kiri): Pokok, Gedhang Salirang, Empyak Satangkep, Gedhang Setangkep, Cere Gancet, Trajumas, dan Barengan

Omah Jawa secara dasar setidaknya terdiri dari satu unit omah tanpa pendopo dan pringgitan. Satu unitnya terdiri dari dua bagian; luar dan dalam. Bagian dalam terdiri dari ruang tengah disebut dalem dan deretan kamar-kamar di belakang yang disebut senthong; kiwa, tengah, dan tengen. Bagian luar depan ada ruang terbuka seperti teras yang disebut dengan emperan (Kartono, 2005).

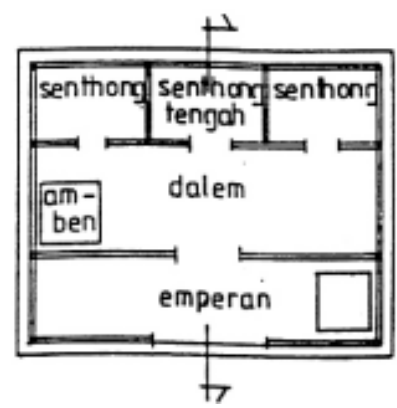

\section{Gambar 3. Denah Dasar Omah}

Omah Panggang Pe, bersama dengan Omah Kampung merupakan rumah rakyat, bukan rumah bangsawan. Rumah-rumah bangsawan lebih cenderung menggunakan Omah Limasan dan Omah Joglo (Cahyandri, 2012). Omah Panggang Pe ini lebih umum ditemukan di wilayah pesisir Pantai Utara. Wilayah ini merupakan wilayah kekuasaan Kesultanan Demak, Cirebon, hingga Mataram Islam.

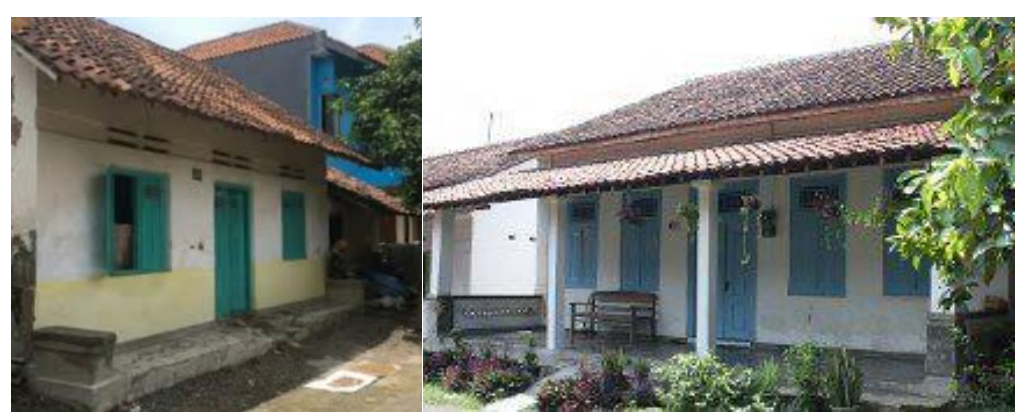

Gambar 4. Rumah Panggang Pe di Tegal: tanpa tambahan tritisan depan (kiri) dan dengan tambahan tritisan (kanan) 
Bagaimanakah karakteristik dengan Omah Sengen di Banten Lor? Apakah ada elemen yang dilanjutkan dan elemen yang dirubah? Penelitian ini akan mecoba menjawabnya.

\section{Metode Penelitian}

Penelitian ini merupakan penelitian kualitatif dengan pendekatan studi kasus. Data-data diterima dari lapangan, baik melalui observasi, FGD dan wawancara langsung. Sedangkan datadata literatur digunakan untuk memperkuat hasil analisis. Lalu data-data tersebut diolah dan dianalisis hingga ditentukan kasimpulannya (Sugiyono, 2012).

Data-data lapangan yang sudah diolah akan dianalisis berdasarkan tiga sistem karakteristik arsitektur menurut Habraken (1998), yaitu:

1. Sistem spasial: pola ruang, orientasi, hirarki

2. Sistem fisik dan kualitas figural: wujud fisik, bahan/material, dan pembatas ruang

3. Sistem stilistik: atap, kolom, bukaan, dan ornamen

Pada Tabel 2 adalah Karakteristik Arsitektur Omah Panggang Pe.

Tabel 2. Karakteristik Arsitektur Omah Panggang Pe

\begin{tabular}{|l|l|}
\hline \multicolumn{2}{|c|}{ Karakteristik Arsitektur Omah Panggang Pe Pantai Utara Jawa } \\
\hline Sistem Spasial & \\
\hline Organisasi Ruang & Linier: Emperan - Dalem - Senthong \\
\hline Surkulasi & Linier: Emperan - Dalem - Senthong \\
\hline Orientasi & Utara - Selatan dan Kiblat \\
\hline Hirarki Ruang & Publik - Privat : Emperan - Dalem - Senthong \\
\hline Sistem Fisik dan Kualitas Figural & \\
\hline Wujud dan Bentuk & Panggang Pe Pokok \\
\hline Material & $\begin{array}{l}\text { Konstruksi Atap: Kayu } \\
\text { Penutup Atap: Rumbia atau Genteng } \\
\text { Kolom: Kayu } \\
\text { Lantai: Tanah Liat dan Teraso } \\
\text { Pondasi: Umpak }\end{array}$ \\
\hline Pembatas & $\begin{array}{l}\text { Dinding: Gedek atau Bata } \\
\text { Lapisan: Tanah Liat dan Kapur }\end{array}$ \\
\hline Sistem Stilistik & Panggang Pe Pokok (tanpa atau dengan tambahan tritisan di depan) \\
\hline Atap & Dua belas buah (Sakarolas) \\
\hline Kolom & Pintu dan Jendela Kayu \\
\hline Bukaan & Tanpa atau minim ornamen \\
\hline Ornamen &
\end{tabular}

Objek penelitian ditentukan berdasarkan rumah yang masih mempertahankan denah aslinya, sedikit perubahan pada fisiknya, dan umurnya. Selain itu, ada faktor kendala yang sangat mempengaruhi ijin tuan rumah di masa Pandemi COVID-19. Oleh karena itu, dipilihlah dua lokasi di Cilegon sebagai objek penelitian; Ciwedus dan Purwakarta. 


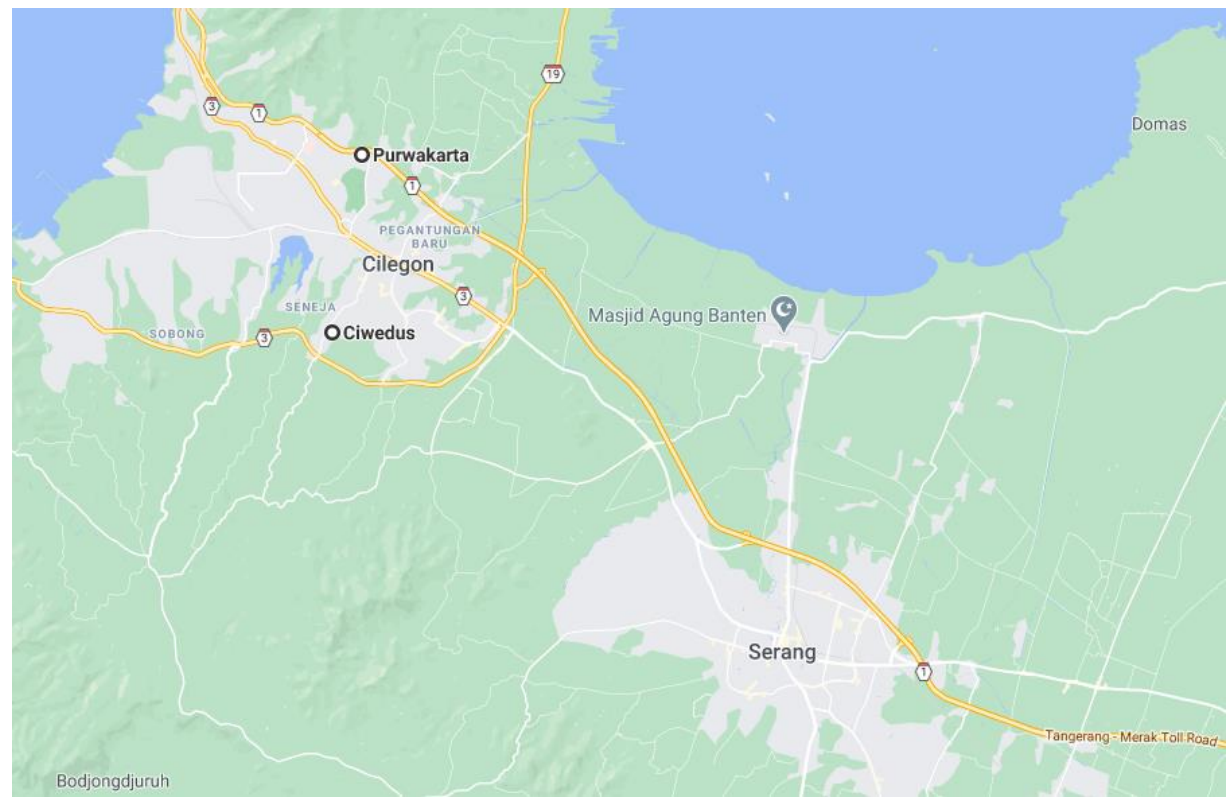

Gambar 5. Lokasi Penelitian

\section{Hasil dan Pembahasan}

\section{Ciwedus}

Bangunan rumah ini memiliki orientasi ke jalan, di mana bagian depannya menghadap ke selatan dan bagian belakangnya menghadap ke utara. Sehingga sirkulasi udara rumah ini baik dan mengikuti pola orientasi rumah Jawa yang agak menghadap Utara-Selatan namun cenderung mengikuti kiblat. Arah ini mengingatkan dengan karakter Kampung Lengkong Kyai (Khamdevi, 2012). Pola ruang rumah di Ciwedus cenderung memiliki organisasi ruang linier dan sirkulasi linier. Nama-nama ruangan cenderung menggunakan istilah-istilah yang umum pada etnis Sunda. Di depan luar rumah terdapat ruang teras yang disebut beubancik atau sasoro yang bersifat publik sebagai ruang sosial dengan tetangga. Di bagian dalam terdapat ruang tengah yang disebut sesuruh yang bersifat semi-publik untuk menerima tamu yang diijinkan masuk, dan di belakang terdapat kamar tidur pada kanan dan kiri yang disebut seurumah yang bersifat privat. Di antara kamar itu terdapat salang, yaitu ruang selasar menuju belakang luar rumah. Jika di rumah Jawa di tengah ada senthong tengah yang berfungsi sebagai tempat penyimpanan, di rumah ini justru ruang penyimpanan ada di atasnya dengan diberi kayu dan bambu yang melintang di antara dua kamar tidur yang berfungsi untuk penyimpanan hasil bumi. Di luar belakang terdapat pawon (dapur), beurimah (halaman belakang), dan keuce'mberan (kolam dan jamban). 


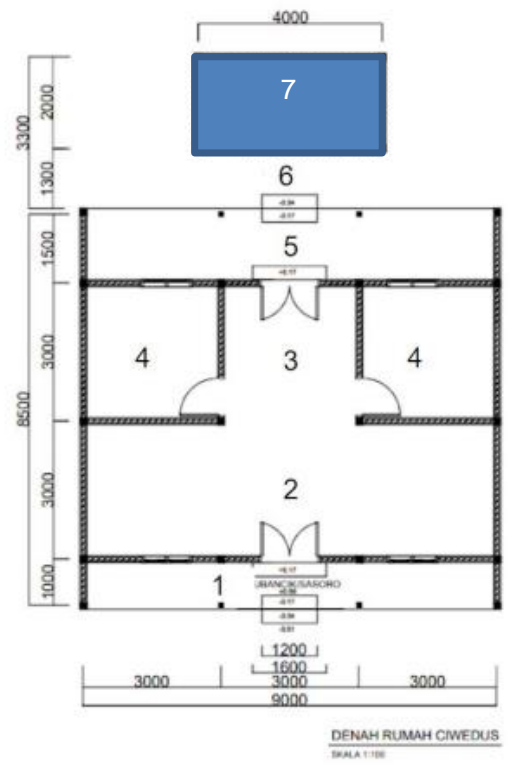

\section{KETERANGAN :}

1. Beubancik / sasoro = teras depan

2. Sesuruh $=$ ruang penerima tamu

3. Salang $=$ ruang tengah $/$ keluarga

4. Seurumah $=$ ruang tidur

5. Pawon = ruang belakang rumah / dapur

6. Beurimah $=$ halaman di belakang rumah

7. Keuce'mberan $=$ kolam dan jamban

\section{Gambar 6. Denah Rumah Ciwedus}

Berdasarkan interview, rumah ini masuk pada jenis Panggang Pe Pokok, yang disebut oleh warga setempat dengan undak usuk. Karena adanya penyesuaian, seakan-akan rumah ini seperti tipe Omah Kampung. Namun perbedaannya terdapat pada konstruksi rumah dan atapnya, di mana ada penambahan teritisan pada ruang sasoro yang bertumpu pada tiang ceucagak, di mana atap ini disisipkan di bawah atap utama yang bertipe pelana, kadang atap terlihat seperti terpisah atau seakan-akan bersambung. Rumah dengan rumah berderet menyamping sambung-menyambung dengan rumah tetangga dengan satu dinding. Wujud dan bentuk rumah sangat sederhana dan fungsional. Material atap dulunya adalah welit (rumbia atau pohon kelapa yang dikeringkan), namun sekarang adalah genteng lentong dari keramik tanah liat. Dinding terbuat dari bata mentah yang dilapisi tanah liat dan kapur (/uluh). Jendela dan pintu berbahan kayu. Lantai lama adalah tanah liat, namun sekarang sudah dilapisi teraso.
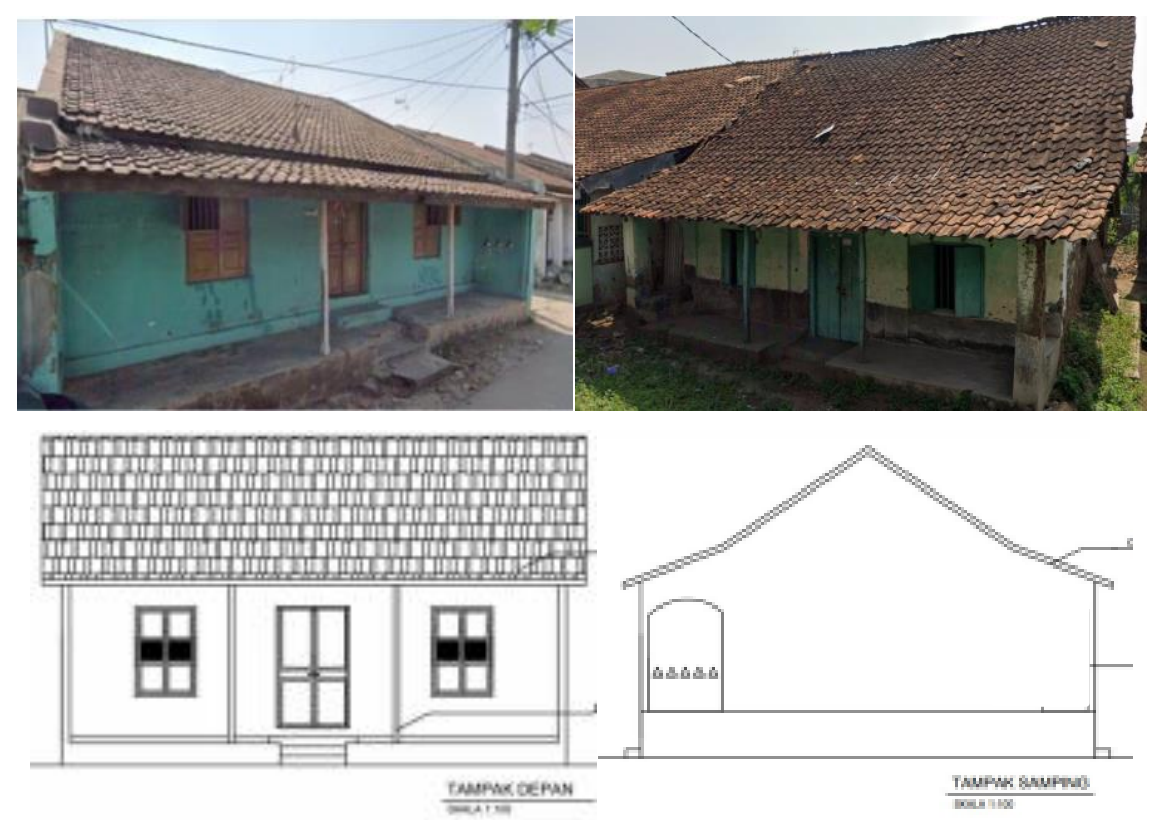

Gambar 7. Foto dan Tampak Rumah Ciwedus

Jumlah kolom utamanya ada dua belas buah (sakarolas). Pada dinding sebelah kanan dan kiri 120 | Volume 4 Nomor 2 Februari 2021 
sasoro terdapat jendela melengkung seperti kubah tanpa daun jendela. Namun sekarang jendela ini di beberapa rumah sudah ditutup dan diberi rooster oleh pemilik rumah karena untuk menghindari debu kendaraan dari jalan. Jendela berkarakter arab-islam ini sangat umum kita temukan pada rumah-rumah tradisional di Lengkong Kyai (Khamdevi, 2013), rumah kongsi Tionghoa di Banten Lama, rumah indis kolonial di Pekojan-Serang, dan rumah-rumah tradisional betawi yang sering disebut melompang. Selain itu pada kamar-kamar tidur, dan ruang tengah terdapat cerukan berbentuk segitiga agak melengkung pada dinding yang disebut lembedang (tembok berlubang), yang berfungsi sebagai tempat lampu minyak atau menyimpan Al-Qur'an.

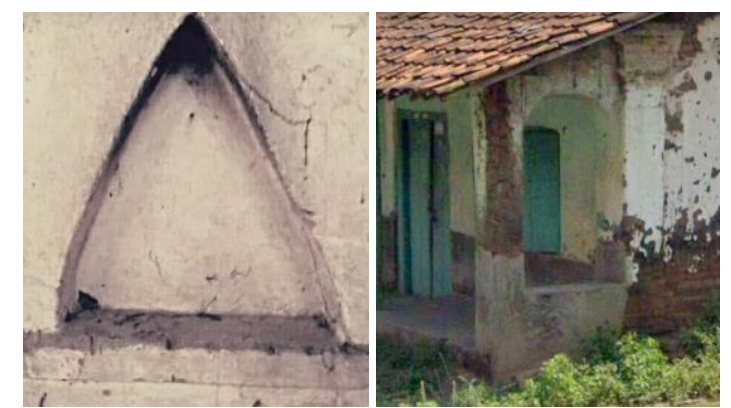

Gambar 8. Jendela Lengkung Kubah dan Lembedang

\section{Purwakarta}

Bangunan rumah ini hanya tinggal satu-satunya di wilayah ini, karena rumah-rumah lain direnovasi berubah tidak seperti aslinya lagi melalui program rumah bedah pihak pemerintah. Rumah ini berorientasi ke jalan setapak agak mengikuti arah Utara-Selatan dan cenderung mengikuti arah kiblat. Sama dengan Ciwedus, pola ruang rumah ini memiliki organisasi ruang linier dan sirkulasi linier. Ruang-ruang, fungsi dan hirarkinya juga cenderung sama persis, jadi tidak perlu dijelaskan kembali.

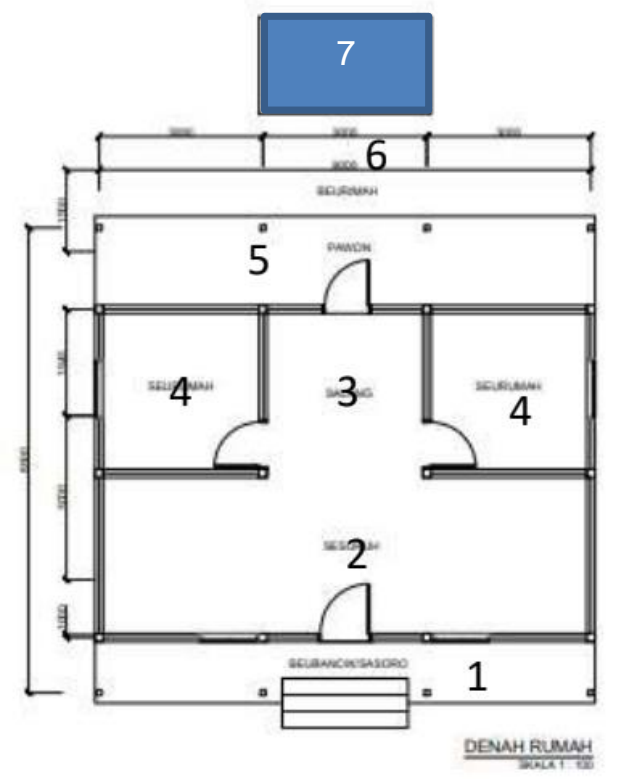

Keterangan:

1. Beubancik/sosoro : teras depan

2. Sesuruh: ruang tamu

3. Salang: ruang tengah

4. Seurumah: ruang tidur

5. Pawon: dapur

6. Beurimah: halaman belakang

7. Keuce'mberan: jamban

Gambar 9. Denah Rumah Purwakarta

Jumlah kolom utamanya ada dua belas buah (sakarolas). Terdapat empat tiang ceucagak menyangga teritisan pada ruang sasoro. Teritisan dan atap utama memiliki konstruksi yang terpisah, namun tampak dari luar seperti menyambung. Material atap berupa genteng keramik tanah liat. Rumah ini tidak 
Kajian Karakteristik Arsitektur Omah Sengen Etnis Jawe Di Banten Lor

memiliki jendela lengkung kubah pada dinding sisi kiri dan kanannya. Dinding bata mentah yang dilapisi tanah liat dan kapur. Pada dinding kamar dan ruang tengah terdapat lembedang. Lantai tanah liat dilapisi teraso. Jendela dan pintu berbahan kayu.

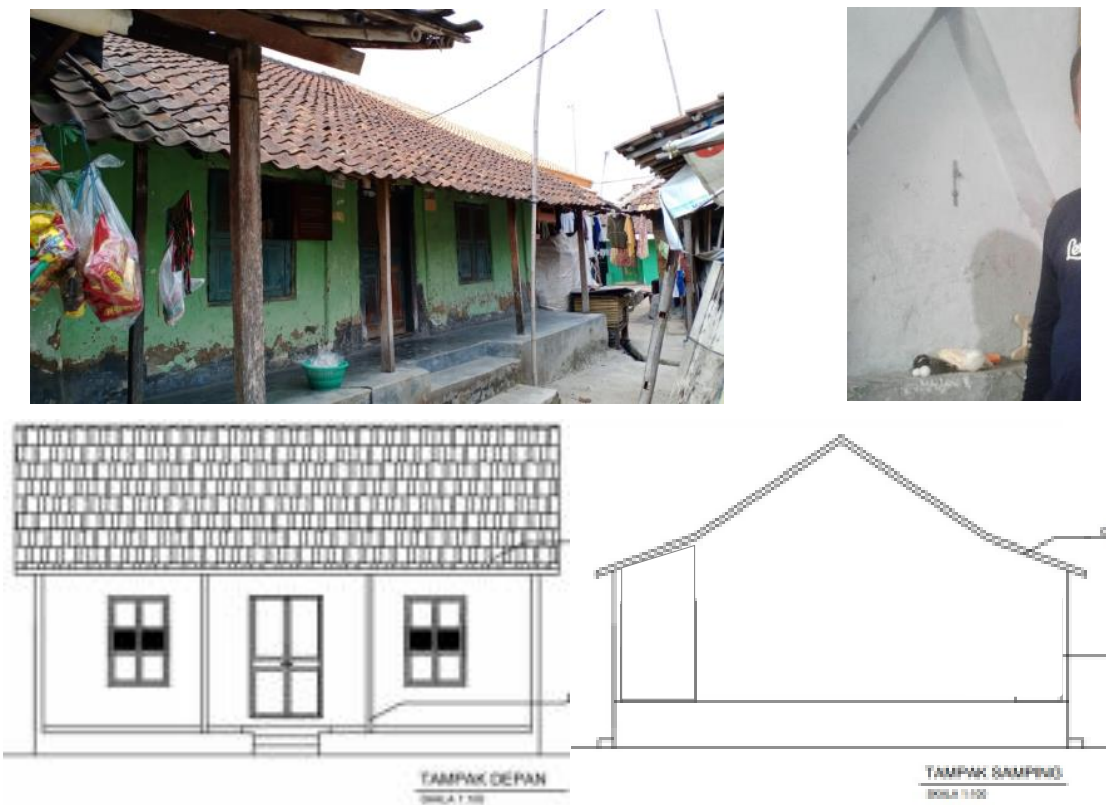

Gambar 10. Foto, Lembedang dan Tampak Rumah Ciwedus

Dari kedua studi kasus tadi, maka data akan dianalisis dengan cara membandingkannya satu sama lain dan juga dengan Rumah Panggan Pe secara umum, lihat Tabel 3. Dapat diketahui bahwa Omah Sengen memiliki keterkaitan dengan Omah Panggang Pe di wilayah Pantai Utara Jawa.

Tabel 3. Karakteristik Arsitektur Omah Sengen di Ciwedus dan Purwakarta

\begin{tabular}{|c|c|c|c|}
\hline \multicolumn{4}{|c|}{ Karakteristik Arsitektur Omah Panggang Pe } \\
\hline Sistem Spasial & Panggang Pe Pantai Utara & Ciwedus & Purwakarta \\
\hline Organisasi Ruang & Linier: Emperan - Dalem - Senthong & $\begin{array}{l}\mathrm{V}^{*} \\
\text { (menghilangkan kamar } \\
\text { tengah untuk selasar) }\end{array}$ & $\begin{array}{l}\mathrm{V}^{*} \\
\text { (menghilangkan kamar } \\
\text { tengah untuk selasar) }\end{array}$ \\
\hline Surkulasi & Linier: Emperan - Dalem - Senthong & $\begin{array}{l}\mathrm{V}^{*} \\
\text { (menghilangkan kamar } \\
\text { tengah untuk selasar) }\end{array}$ & $\begin{array}{l}\mathrm{V}^{*} \\
\text { (menghilangkan kamar } \\
\text { tengah untuk selasar) }\end{array}$ \\
\hline Orientasi & Utara - Selatan & $\begin{array}{l}V^{*} \\
\text { (kiblat) }\end{array}$ & $\begin{array}{ll}V^{*} \\
\text { (kiblat) }\end{array}$ \\
\hline Hirarki Ruang & Publik - Privat : Emperan - Dalem - Senthong & & \\
\hline \multicolumn{4}{|l|}{$\begin{array}{l}\text { Sistem Fisik dan } \\
\text { Kualitas Figural }\end{array}$} \\
\hline Wujud dan Bentuk & Panggang Pe Pokok & $\mathrm{v}$ & $\mathrm{V}$ \\
\hline Material & $\begin{array}{l}\text { Konstruksi Atap: Kayu } \\
\text { Penutup Atap: Rumbia atau Genteng } \\
\text { Kolom: Kayu } \\
\text { Lantai: Tanah Liat dan Teraso } \\
\text { Pondasi: Umpak }\end{array}$ & $\sqrt{ }$ & $\mathrm{V}$ \\
\hline Pembatas & $\begin{array}{l}\text { Dinding: Gedek atau Bata } \\
\text { Lapisan: Tanah Liat dan Kapur }\end{array}$ & $\sqrt{ }$ & $\sqrt{ }$ \\
\hline \multicolumn{4}{|l|}{ Sistem Stilistik } \\
\hline Atap & $\begin{array}{l}\text { Panggang Pe Pokok (tanpa atau dengan } \\
\text { tambahan tritisan di depan) }\end{array}$ & $\begin{array}{l}\checkmark \\
\text { (dengan tritisan) }\end{array}$ & $\begin{array}{l}\mathrm{V} \\
\text { (dengan tritisan) }\end{array}$ \\
\hline Kolom & Dua belas buah (Sakarolas) & $\sqrt{ }$ & $\mathrm{V}$ \\
\hline Bukaan & Pintu dan Jendela Kayu & $\mathrm{V}$ & $\mathrm{V}$ \\
\hline Ornamen & Tanpa atau minim ornamen & $\begin{array}{l}\text { Lembedang dan Jendela } \\
\text { Lengkung Kubah }\end{array}$ & Lembedang \\
\hline
\end{tabular}




\section{Kesimpulan}

Omah Sengen memiliki karakteristik rumah Jawa yang bertipe Panggang Pe Pokok. Karakter keruangannya sebagian besar dilanjutkan, namun istilah nama ruang dan kamar tengah ditiadakan dan diangkat ke atas loteng untuk menciptakan selasar atau lorong ke belakang, disesuaikan dengan kebutuhan baru. Karakter fisik dan kualitas figuralnya Omah Panggang Pe dilanjutkan namun disesuaikan seakan-akan seperti Omah Kampung dengan penambahan teritisan di atas teras depan. Karakter stilistiknya melanjutkan aturan tiang sakarolas, konstruksi atap Panggang Pe, dan elemen lembedang serta jendela lengkung kubah, sedangkan material bangunan disesuaikan dengan ketersediaan saat ini dan kemampuan pemiliknya, lihat Tabel 4. Melalui penelitian ini dapat disimpulkan pula bahwa etnis Jawe berasal dari wilayah Pantai Utara Jawa sekitar Demak dan Cirebon, dan menghuni wilayah pesisir utara Banten sejak abad ke-16. Mereka membawa budaya mereka, terutama rumah tradisionalnya dengan adanya elemen yang dilanjutkan dan elemen yang dirubah dengan penyesuaian-penyesuaian di masa Kesultanan Banten dan pengaruh atas interaksi mereka dengan etnis Sunda-Banten dan etnis-etnis di Selatan Sumatera (Lampung, Rejang, Palembang, dan lain-lain).

Tabel 4. Karakteristik Arsitektur Omah Panggang Pe

\begin{tabular}{|l|l|}
\hline \multicolumn{2}{|c|}{ Karakteristik Arsitektur Omah Panggang Pe Pantai Utara Jawa } \\
\hline Sistem Spasial & \\
\hline Organisasi Ruang & Linier: Sasoro - Sesuruh - Seurumah - Pawon \\
\hline Surkulasi & Linier: Sasoro - Sesuruh - Seurumah - Pawon \\
\hline Orientasi & Utara - Selatan dan Kiblat \\
\hline Hirarki Ruang & Publik - Privat : Sasoro - Sesuruh - Seurumah - Pawon \\
\hline Sistem Fisik dan Kualitas Figural & \\
\hline Wujud dan Bentuk & Panggang Pe Pokok \\
\hline Material & $\begin{array}{l}\text { Konstruksi Atap: Kayu } \\
\text { Penutup Atap: Welit atau Genteng } \\
\text { Kolom: Kayu } \\
\text { Lantai: Tanah Liat dan Teraso } \\
\text { Pondasi: Umpak }\end{array}$ \\
\hline Pembatas & $\begin{array}{l}\text { Dinding: Bata } \\
\text { Lapisan: Tanah Liat dan Kapur }\end{array}$ \\
\hline Sistem Stilistik & \\
\hline Atap & Panggang Pe Pokok (dengan tambahan tritisan di depan) \\
\hline Kolom & Dua belas buah (Sakarolas) \\
\hline Bukaan & Pintu dan Jendela Kayu \\
\hline Ornamen & Lembedang dan Jendela Lengkung Kubah (Melompang) \\
\hline
\end{tabular}

\section{Daftar Pustaka}

Cahyandri, G. O. I. (2012). Tata Ruang dan Tata Elemen Arsitektur pada Rumah Jawa di Yogyakarta sebagai Wujud Kategori Pola Aktivitas dalam Rumah Tangga. Jurnal Arsitektur KOMPOSISI Vol. 10 No. 2. Yogyakarta: Universitas Atma Jaya Yogyakarta.

Dakung, Sugiarto (1982). Arsitektur Tradisional Daerah Istimewa Yogyakarta. Yogyakarta: Depdikbud.

Habraken, N. John (1988). Type as Social Agreement. Seoul: Asian Congress of Architect.

Kartono, J. Lukito (2005). Konsep Ruang Tradisional Jawa dalam Konteks Budaya. Jurnal Dimensi 
Kajian Karakteristik Arsitektur Omah Sengen Etnis Jawe Di Banten Lor

Interior Vol. 3 No. 2. Surabaya: Universitas Kristen Petra.

Khamdevi, M. (2012). Kajian Pola Permukiman Khas Kampung Lengkong Ulama, Serpong, Banten. Jurnal Dimensi Vol. 39 No. 1. Surabaya: UK Petra.

Khamdevi, M. (2013). Karakteristik Rumah Tradisional Di Kampung Bersejarah Lengkong Ulama, Kabupaten Tangerang. Jurnal Vitruvian Vo. 3 No. 1. Jakarta: UMB.

Ooi, Keat Gin (2004). Southeast Asia: A Historical Encyclopedia, from Angkor Wat to East Timor. California: ABC-CLIO.

Prijotomo, Josef (1995). Petungan: Sistem Ukuran Dalam Arsitektur Jawa. Yogyakarta: Gadjah Mada University Press.

Sugiyono (2012). Metode Penelitian Kuantitatif Kualitatif dan R\&D. Bandung: Alfabeta.

Tjandrasasmita, Uka (2009). Arkeologi Islam Nusantara. Jakarta: KPG. 
Muhammar Khamdevi 